\title{
The distribution of mercury and other trace elements in the bones of two human individuals from medieval Denmark - the chemical life history hypothesis
}

Kaare Lund Rasmussen ${ }^{1 *}$, Lilian Skytte ${ }^{1}$, Christian Pilekær ${ }^{1}$, Anne Lauritsen ${ }^{1}$, Jesper Lier Boldsen², Peter Mygind Leth ${ }^{2}$ and Per Orla Thomsen ${ }^{3}$

\begin{abstract}
Excavating human skeletons is the closest archaeologists can get to the people who lived in the past. Once excavated the bones are often analysed chemically in order to yield as much information as possible. Most archaeometric analyses performed on samples of human skeletal remains have been performed on a single sample from a tooth or a long bone. In this paper we investigate how a suite of elements ( $\mathrm{Mg}, \mathrm{Al}, \mathrm{Ca}, \mathrm{Mn}, \mathrm{Fe}, \mathrm{Zn}, \mathrm{As}, \mathrm{Sr}, \mathrm{Ba}$, $\mathrm{Hg}$ and $\mathrm{Pb}$ ) are distributed in two medieval skeletons excavated at the laymen cemetery at the Franciscan Friary in Svendborg, Denmark.

The analyses have been performed using CV-AAS for Hg and ICP-MS for the rest of the elements. We find that in general $\mathrm{Hg}$ concentrations are highest in the trabecular tissues and in the abdomen region. Our data also show that the elements $\mathrm{Al}, \mathrm{Fe}$ and $\mathrm{Mn}$ concentrate in the trabecular tissue and on the surfaces of the bones. The two individuals can be clearly distinguished by Principal Component Analysis of all the measured trace elements. Our data support a previously published hypothesis that the elemental ratios $\mathrm{Sr} / \mathrm{Ca}, \mathrm{Ba} / \mathrm{Ca}$ and $\mathrm{Mg} / \mathrm{Ca}$ are indicative of provenance. Aluminium, Fe and Mn can be attributed to various forms of diagenesis, while $\mathrm{Hg}$ is not present in sufficiently large amounts in the surrounding soil to allow diagenesis to explain the high $\mathrm{Hg}$ values in the trabecular tissue. Instead we propose that $\mathrm{Hg}$ must originate from decomposed soft tissue.
\end{abstract}

Keywords: Human bones, Medieval, Chemical life history, Mercury, Trace elements

\section{Introduction}

Indicators of diet, provenance, occupation and medical treatment of medieval humans are increasingly being investigated by trace element analyses in the skeletal remains procured from archaeological excavations. These analyses are normally performed on a single sample from the skeleton of an individual, often a tooth or the compact part of the largest bone in the human body - the femur. However, little attention has been given to the distribution of the trace elements between different bone elements in the same skeleton. Grupe [1] discriminated between

\footnotetext{
* Correspondence: klr@sdu.dk

'Institute of Physics, Chemistry and Pharmacy, University of Southern Denmark, Campusvej 55, Odense M DK-5230, Denmark

Full list of author information is available at the end of the article
}

compact and trabecular bone tissues and reported average trace element concentrations of $\mathrm{Mg}, \mathrm{P}, \mathrm{Ca}, \mathrm{Zn}, \mathrm{Sr}$ and $\mathrm{Ba}$ in the two types of tissue. Concentrations in different tissue types in modern man were reported in the comprehensive report Reference Man [2]. In this work we present trace element analyses of 36 different parts of the skeletons of two medieval human individuals excavated in Denmark. The two individuals were selected based on a larger survey by Rasmussen et al. [3] reporting the $\mathrm{Hg}$ concentrations in single samples of compact bone tissue in each individual, mostly from the femur, and including more than hundred individuals. The first individual selected for this study exhibited an elevated Hg concentration in the analysis of a single sample from the femur, indicating that this individual had been exposed to $\mathrm{Hg}$, probably through medical treatment with $\mathrm{Hg}$. The other 
individual was selected because the single femoral sample featured an $\mathrm{Hg}$ concentration at the background level, which indicated that the individual was not exposed to $\mathrm{Hg}$ above the environmental background level.

The samples were subjected to two analytical methods: CV-AAS for $\mathrm{Hg}$ and ICP-MS for $\mathrm{Mg}, \mathrm{Al}, \mathrm{Ca}, \mathrm{Mn}, \mathrm{Fe}$, $\mathrm{Zn}$, As, $\mathrm{Sr}, \mathrm{Ba}$ and $\mathrm{Pb}$. Our results show significant differences between the trace element concentrations in the various bone tissues, most notably between compact and trabecular tissue. It is the first time that a study of the bone trace element chemistry has been conducted to this level of detail on Danish medieval skeletons.

\section{Excavation site and bone material}

The Franciscan Friary in Svendborg was founded in 1236 (Figure 1). Svendborg is situated on the south coast of the island of Fyn in Denmark (Additional file 1). The buildings of the friary were modified and enlarged over the centuries and in 1361 a new gothic church was consecrated by Bishop Niels Jonsen from Odense. A layman cemetery was situated to the south of the friary's church [4]. To the east, the premises of the friary were bordered by the coastline. To the west was an elevated ground where the medieval city was situated. Excavations in 1975-1977 and again in 2007 revealed extremely well preserved burials in the laymen cemetery; in some individuals even brain tissue was preserved. The reason for the fine state of preservation was undoubtedly the highly anoxic and groundwater saturated low-porosity clay-rich soil.

A series of individuals excavated from the cemetery in 1975-77 have previously been sampled for compact bone tissue which were analysed in triplicate for $\mathrm{Hg}$ by Cold Vapour Atomic Absorption Spectroscopy (CV-AAS) [3]. On this basis two individuals were selected. One individual, AG93 (KLR-6578 in [3]; the present samples are designated KLR-8601), exhibited a very low $\mathrm{Hg}$ concentration of $16.6 \pm 1.2 \mathrm{ng} \mathrm{g}^{-1}$, which is typical of non-exposed individuals. The other individual, AG104 (KLR-6577 in [3]; the present samples are designated KLR-8602), had a Hg concentration of $273 \pm 43 \mathrm{ng} \mathrm{g}^{-1}$, which is relatively high, and certainly elevated above the normal background of 10$100 \mathrm{ng} \mathrm{g}^{-1}$, and it is therefore likely that AG104 experienced an intra vitam exposure to $\mathrm{Hg}$.

AG93 was a 38-45 years old male. A lesion to the nasal region makes it probable that he was once in a fight or had an accident. AG104 was a 17-19 years old male (note the revised sexing and age estimation of this individual compared to [3]). Neither individual had distinct signs of $\mathrm{TB}$, leprosy or syphilis.

The bone samples were procured by drilling. Before taking a sample of compact bone tissue any contamination residing on the bone surface was removed mechanically in all but one case from each skeleton. The trabecular samples were simply drilled out as found, as (a)

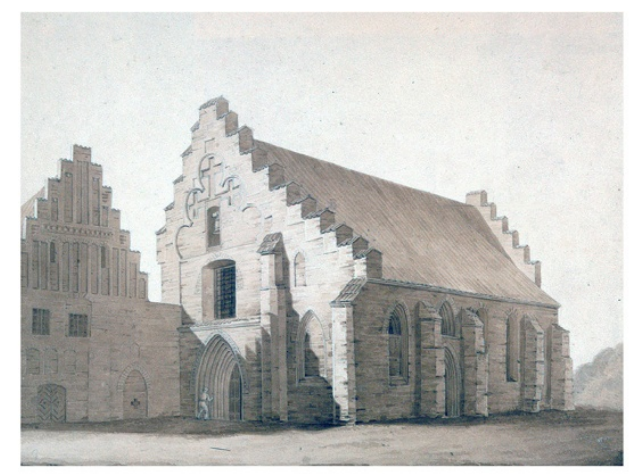

(b)

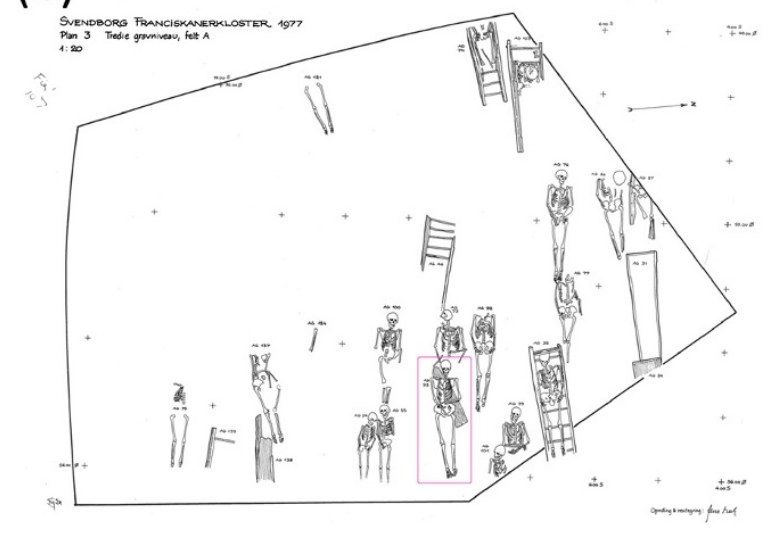

(c)

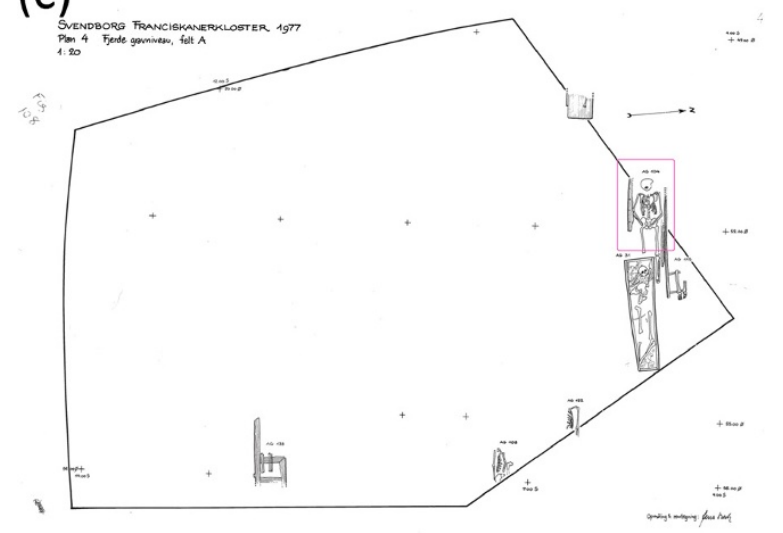

Figure 1 The archaeological site, the Franciscan Friary in Svendborg, Demark. a: The Franciscan Friary in Svendborg just prior to demolition in 1828. Watercolour by C.F. Thorin 1828 now at the National Museum of Denmark; $\mathbf{b}$ : The excavation plan of the lay cemetery at Svendborg Franciscan Friary (field A) showing the excavation level 3 and the position of AG93 at depth $6.11 \mathrm{~m}$ (violet rectangle); c: Same field, excavation level 4, the position of AG104 at depth $5.94 \mathrm{~m}$ is indicated by a violet rectangle; from Svendborg County Museum 1977. 
no mechanical de-contamination is possible on this type of tissue. There is no question that the trabecular tissues are at all times augmented by decomposed soft tissue collapsing onto the bone lamellae, and occasionally polluted by invading soil, as will be abundantly clear in the results section of this paper. The soils of Denmark are generally a mixture of organic matter and glacial deposits, which is a mixture of mainly clay but also quartz, feldspars and other minerals of very fine grain sizes capable of penetrating small cavities and cracks.

Prior to sampling the drill and all other stainless steel utensils were rinsed in distilled water and heated in an ethanol flame in order to rinse off any dust particles and water soluble salts and evaporate any $\mathrm{Hg}$ possibly present as contamination. Gloves, hairnet and face mask were used during sampling. The drill used was a Dremel MultiPro $^{\circledR}$ electric drill model 395 with adjustable drilling velocity, operated at low velocity and equipped with a $2 \mathrm{~mm}$ diameter drill. In preparation for sampling, the working table was covered with a large sheet of clean white paper. A sheet of clean aluminium foil was placed on top of the paper. The bone was placed on the Al-foil and the drill was taken into the ethanol flame and left to cool ca. 30 seconds. Then a surface area of 1 to $2 \mathrm{~cm}^{2}$ was removed by drilling in order to rid the bone of the surface. The bone was brushed gently to remove remaining dust, and the $\mathrm{Al}$-foil together with the surface material was removed and discarded. After rinsing and reheating the drill and letting it cool again, the drilling of the compact bone material was carried out on top of a new clean sheet of Al-foil. The drilled sample was transferred to a pre-cleaned glass and sealed. For the trabecular samples the procedure was the same except no decontamination of the bone surface could be performed prior to sampling.

Thirty seven samples were taken from skeleton AG93 and 36 samples from AG104. In the long bones all samples were taken from the dorsal/posterior, proximal part of the bone with the exception of the set of compact bone samples from left femur and humerus. These samples were taken with an equivalent distance along the dorsal surface of the left femur and humerus in both skeletons. Table 1 summarizes the places in the skeleton from where the samples were extracted. Each sample had a weight of 20 to $40 \mathrm{mg}$.

\section{Analytical techniques ICP-MS}

Trace elements were measured by ICP-MS (Inductively Coupled Plasma Mass Spectroscopy). Each sample of ca. $20 \mathrm{mg}$ was dissolved in a mixture of $2 \mathrm{~mL} \mathrm{HNO}_{3}, 1 \mathrm{~mL}$ $\mathrm{H}_{2} \mathrm{O}_{2}$, and $0.67 \mathrm{~mL} \mathrm{HCl}$ all concentrated and all of ICPMS grade. This took place in new, sealed polystyrene containers on a shaking table for 24 hours at room
Table 1 Summary of the bone elements sampled in AG93 and AG104

\begin{tabular}{lll}
\hline & AG93 & AG104 \\
\hline Femur compact & 2 & 2 \\
Femur trabecular & 2 & 2 \\
Femur compact extra & 11 & 11 \\
Tibia compact & 1 & 1 \\
Tibia trabecular & 1 & 1 \\
Humerus compact & 2 & 2 \\
Humerus trabecular & 2 & 2 \\
Humerus compact extra & 7 & 7 \\
Ulna compact & 1 & 1 \\
Ilium & 1 & 1 \\
Sacrum & 3 & 3 \\
Ribs & 2 & 2 \\
Vertebra & 1 & 1 \\
Tubular bone from foot & 1 & 0 \\
Total number of samples & $\mathbf{3 7}$ & $\mathbf{3 6}$ \\
\hline
\end{tabular}

temperature $\left(\mathrm{ca} .20^{\circ} \mathrm{C}\right)$. The samples were then divided and half was used for ICP-MS the other half for CVAAS. The samples were diluted to $10 \mathrm{~mL}$ with Milli-Q water and filtered through $0.45 \mu \mathrm{m}$ PVDF Q-Max disposable filters. The solutions were then stored at $+4^{\circ} \mathrm{C}$ until the analyses were performed.

The analyses were carried out on a Bruker ICP-MS 820 , equipped with a frequency-matching RF generator and a Collision Reaction Interface (CRI), operating with helium or hydrogen. The basic parameters were as follows: radiofrequency power $1.40 \mathrm{~kW}$, plasma gas flow 15.50 L min ${ }^{-1}$; auxiliary gas flow $1.65 \mathrm{~L} \mathrm{~min}^{-1}$; sheath gas flow $0.12 \mathrm{~L} \mathrm{~min}^{-1}$; nebulizer gas flow $1.00 \mathrm{~L} \mathrm{~min}^{-1}$. The CRI Reaction System was activated for As and Fe because of interferences with polyatomic species produced by a combination of isotopes coming from the argon plasma, reagents and matrix. A mixture of Sc45, Y89 and Tb159 was used as internal standard added to all analyses. The following isotopes were measured without skimmer gas: Mg24, Al27, Ca44, Mn55, Zn66, Sr88, Ba137 and a combination of $\mathrm{Pb}$ isotopes (Pb206, Pb207 and $\mathrm{Pb} 208)$. Fe56 was measured with hydrogen as skimmer gas. As75 was run with helium as skimmer gas. The dwell time on each peak was $30 \mathrm{~ms}$. There were made 5 replicate analyses of each sample and each replicate consisted of 30 mass scans. Multi-element calibration standards were prepared in $1 \% \mathrm{HNO}_{3}$ at 6 different concentrations $\left(0,1,10,20,100\right.$ and $\left.200 \mu \mathrm{g} \mathrm{L} \mathrm{L}^{-1}\right)$, but for each element only 3 standards were selected to fit the appropriate concentration range in the samples. For the main element $\mathrm{Ca}$ three standards of 10, 20 and $25 \mathrm{wt} \%$ were run. The average overall uncertainties of the 
reported element concentrations were (RSD at $1 \sigma$ expressed in \%): Mg: 4.2; Al: 2.6; Ca: 2.0; Mn: 1.8; Fe: 6.9; Zn: 2.0; As: 4.6; Sr: 1.8; Ba: 1.1; and Pb: 2.2 .

\section{CV-AAS}

Mercury was measured by cold vapour atomic absorption on a dedicated mercury analyzer, a Flow Injection Mercury System (FIMS-400) manufactured by PerkinElmer and equipped with an S10 autosampler. This system featured a better detection limit for $\mathrm{Hg}$ than the ICP-MS, which occasionally tended to be overloaded with $\mathrm{Hg}$ from the continuous daily analyses of bones, some of which were high in $\mathrm{Hg}$. Two hours prior to analysis $1 \mathrm{~mL}$ of concentrated $\mathrm{KMnO}_{4}$ was added to $10 \mathrm{~mL}$ of sample in order to maintain $\mathrm{Hg}$ on ionic form. The sample was then diluted to $20 \mathrm{~mL}$. In the reaction chamber of the FIMS-400 the $\mathrm{Hg}$ was released as vapour by adding $\mathrm{NaBH}_{4}$. The analyzer was operated in the continuous flow mode. The overall uncertainties, i.e. including reproducibility and dilution, was estimated to be ca. $\pm 10 \%(1 \sigma)$, and the LOD was ca. $1.5 \mathrm{ng} \mathrm{g}^{-1}$ for a human bone sample of ca. $20 \mathrm{mg}$.

An in-house human bone standard was dissolved daily together with the bone samples and included in the daily runs in both ICP-MS and CV-AAS in order to monitor any drift in the systems. However, the inherent inhomogeneity in the in-house standard (70-100 $\mathrm{ng} \mathrm{g}^{-1}$ ) was in all normal cases larger than the analytical uncertainty.

\section{CT-scanning}

A Siemens Somatom Spirit dual slice CT-scanner was used to determine the compactness of the trabecular bone tissue in immediate proximity to the sampling sites. The CT-images were viewed on a Siemens Syngo MultiModality workstation (software syngoMMWP version VE31A). The scanning parameters were as follows: current $57 \mathrm{~mA}$, tension $130 \mathrm{kV}$, slice thickness $3 \mathrm{~mm}$, pitch 0.95 , rotation time $1.0 \mathrm{~s}$, Field of View $200 \mathrm{~mm}$, and system de-convolution kernel U90 (ultrahigh resolution). The Hounsfield-values were calibrated to -1000 for air and 0 for a pure water phantom. Normal Hounsfield-values for compact bone tissue were varying very little and exhibited an average of 1800 . The observed Hounsfield-value for trabecular tissue, $H$, can be expressed:

$$
H=1800 k-1000(1-k)
$$

where $k$ is the compactness ranging from 0 to 1 . Solving this equation yields for the compactness:

$$
k=(H+1000) / 2800
$$

Some elements are not very mobile in the grave either because they have low solubility mainly due to the formations of sulphides or because they adsorb readily to the surfaces of the bones after decomposition of the soft parts of the body. In individuals where the concentration of an immobile element is in equilibrium between compact bone (concentration $C_{c}$ ), trabecular bone (concentration $C_{t}$ ), and soft tissue, the relative trabecular bone concentration, $R C_{t}$, is one. $R C_{t}$ can be estimated from the average compact bone concentration and the degree of compactness, $k$, in the following way:

$$
R C_{t}=C_{t} \cdot k / C_{c}
$$

\section{Results}

The results of the measurements of the elemental concentrations measurements are listed in Additional file 2: Table S1 together with Relative Standard Deviations at $\pm 1 \sigma$ expressed in \% of the concentration. The compactnessvalues measured by CT-scanning are also listed in Additional file 2: Table S1. In the last two lines of Additional file 2: Table S1 are listed the average concentrations of the in-house bone standard and the standard deviations on the average concentrations.

The variation of the elements has been analyzed by Principle Component Analysis. Using two components and eliminating obvious outliers, more than $99 \%$ of the variation can be explained by the first component, PC1, and ca. $1 \%$ by PC2. The factor loadings for the elements can be seen in Figure 2. Iron and $\mathrm{Mn}$ are responsible for most of the variation; $\mathrm{Hg}, \mathrm{Sr}, \mathrm{Ba}, \mathrm{Mg}$ and $\mathrm{Al}$ each are responsible for part of the variation; whereas very little variation results from $\mathrm{Ca}, \mathrm{Zn}, \mathrm{As}$, and $\mathrm{Pb}$. The PCAscores marked according to the two individuals are shown in Figure $3 \mathrm{a}$ and marked according to compact and trabecular bone tissue in Figure $3 \mathrm{~b}$. The two individuals as well as the tissue types can be clearly distinguished in the two plots. The interpretations of the reason for the variation of each element will be

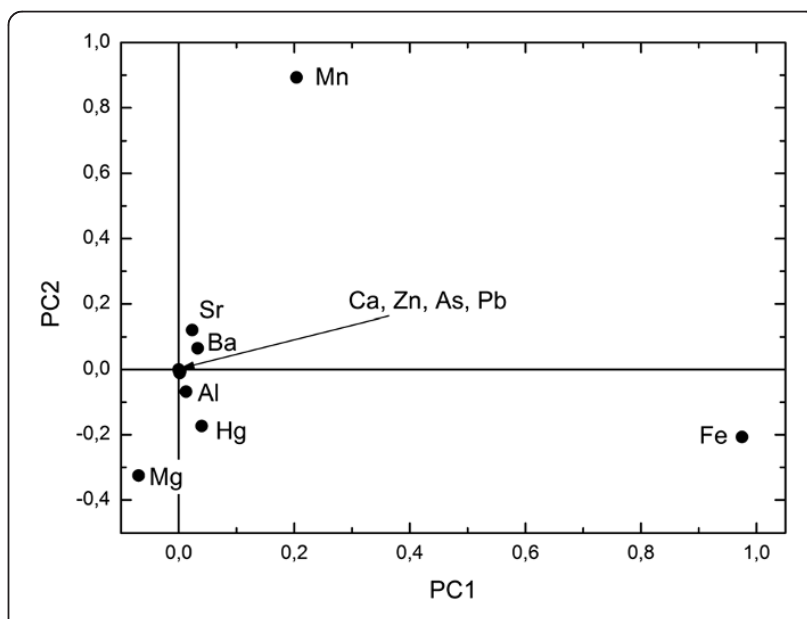

Figure 2 The factor loadings determined by PCA analysis. 

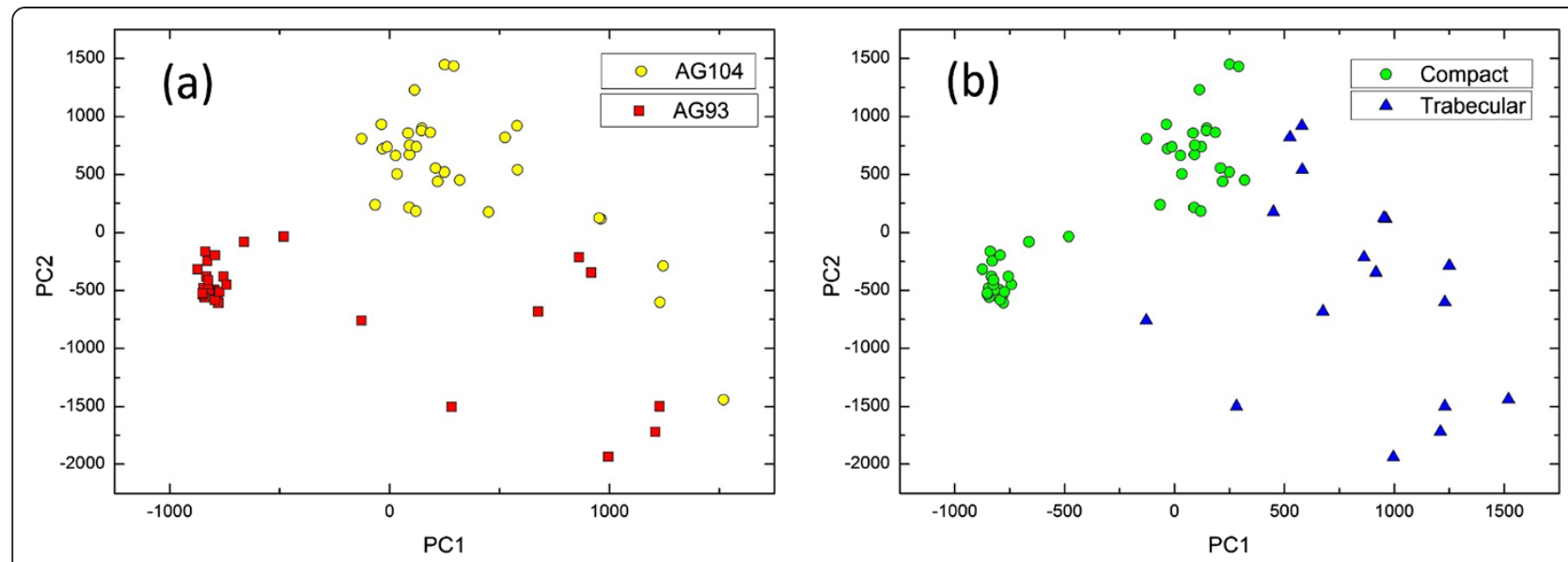

Figure 3 The scores determined by the PCA analysis. a: The factor scores for each sample determined by the PCA analysis: AG104 (yellow circles); AG93 (red squares). b: The factor scores for each sample determined by the PCA analysis (same data as in Figures 3a): compact tissues (green circles); trabecular tissues (blue triangles).

discussed further below. However, in short our interpretations are the following: 1 ) that $\mathrm{Hg}$ is present as a result of a combination of $\mathrm{Hg}$ in background levels and higher concentrations resulting from medication; 2) that $\mathrm{Sr}$, Ba and $\mathrm{Mg}$ substitute for $\mathrm{Ca}$ in the bone apatite and that their variations result from differences in the bioavailable reservoirs of these elements at various geographical locations; 3) that Fe and Mn result from postmortem deposition by groundwater; 4) that $\mathrm{Al}$ originates from soil contamination; and 5) that the rest of the elements are either metabolically controlled or present only at background levels and therefore exhibiting no large variations in the material.

\section{Mercury}

There is very little reason to expect a difference in the $\mathrm{Hg}$ concentrations between the left and the right side of the skeleton, which was indeed not seen in the data of either of the two individuals investigated here, see Figure 4, which shows the $\mathrm{Hg}$ concentrations in the compact bone types. The average $\mathrm{Hg}$ concentrations determined for the compact bone tissue was $52 \mathrm{ng} \mathrm{g}^{-1}$

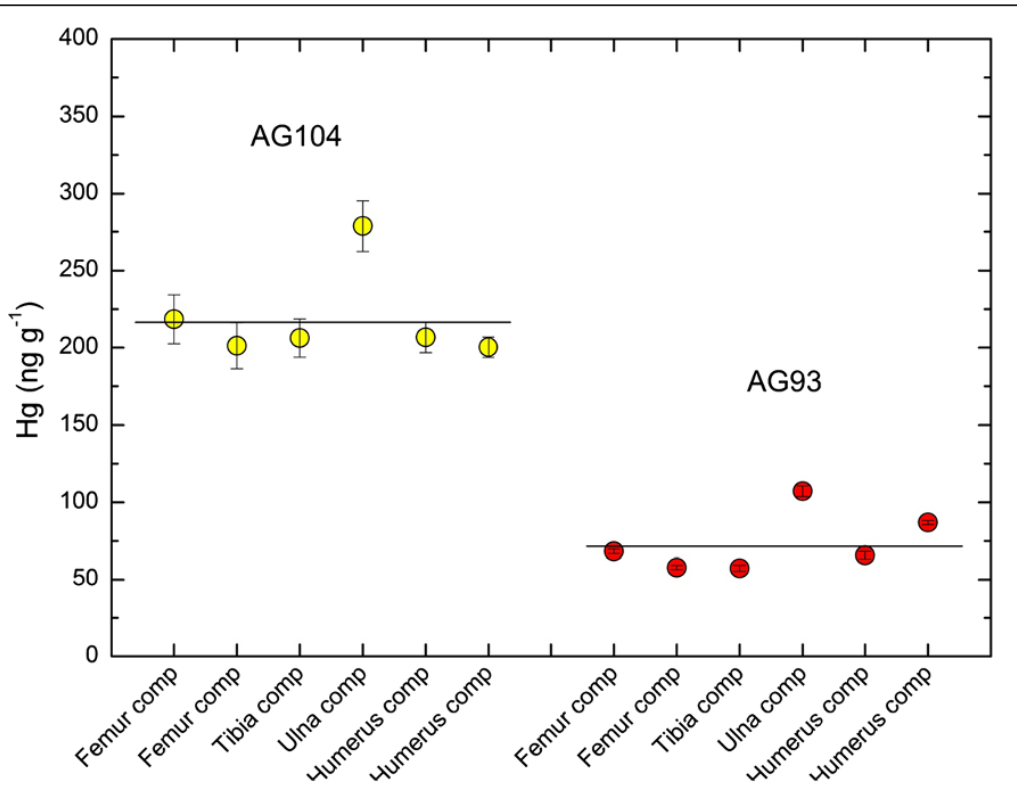

Figure 4 Mercury measured in compact bone tissues. AG93 is shown as red points and AG104 as yellow points. The averages are indicated with horizontal lines. The error bars represent \pm 2 standard deviations of the total analytical uncertainty. Duplicate bone elements are right and left, repectively. 
for AG93 and $127 \mathrm{ng} \mathrm{g}^{-1}$ for AG104 (averages calculated excluding the multiple samples taken along the femur and humerus).

Provided the bone remodelling turnover rate varied among bone positions, a sudden exposure to $\mathrm{Hg}$ relatively late in life (i.e. in adulthood) would result in a large variation in the $\mathrm{Hg}$ concentration measured in different bone locations as they undergo remodelling at different rates. In order to reveal if such variation on the turnover rate exists, a series of 7-8 samples were taken along the backside of the left femur and the left humerus (Figure 5). As can be seen from Figure 5 there is no systematic variation along either the femur or the humerus. For the non-exposed individual AG93, the concentrations are at the background with the only exception of the last sample of the femur, which included small amounts of trabecular tissue. For AG104, who had been exposed to $\mathrm{Hg}$ while alive, the $\mathrm{Hg}$ concentrations were generally higher than in AG93. In both cases our data indicate that there is no systematic variation in the $\mathrm{Hg}$ concentration in the compact tissue along the femur or humerus, and that the bone remodelling rate therefore can be assumed to be the constant along the femur and humerus.

In contradiction to the uniformity of the $\mathrm{Hg}$ in compact tissue, the trabecular tissue exhibited a much greater variation in $\mathrm{Hg}$ concentrations as can be seen in Figure 6 . The $\mathrm{Hg}$ concentrations in trabecular tissue are up to 40 times higher than the in the compact tissue, an observation which will be discussed below.

\section{Aluminium, $\mathrm{Fe}$ and $\mathrm{Mn}$}

The measured $\mathrm{Al}$ concentrations are shown for both individuals in Figure 7. As can be expected little or no contamination or soil invasion was observed in the compact bone tissue. The average $\mathrm{Al}$ concentration the compact bone samples from AG93 was $13.2 \mu \mathrm{g} \mathrm{g}^{-1}$, and $26.4 \mu \mathrm{g} \mathrm{g}^{-1}$ for AG104. In the trabecular tissue the $\mathrm{Al}$ was ranging from 63 to $847 \mu \mathrm{g} \mathrm{g}^{-1}$, which is a factor of up to 50 higher than in the compact tissue. There is normally low levels of $\mathrm{Al}$ in the human skeletal organ $(<1.1$ to $5.0 \mu \mathrm{g} \mathrm{g}^{-1}, 80 \%$ range, [2]), so most of the Al found in this study must originate from clay minerals in soil which has polluted the bones. This is consistent with the up to 50 times higher $\mathrm{Al}$ concentrations sometimes found in the trabecular tissues, which could not be mechanically decontaminated.

The analyses of $\mathrm{Fe}$ and $\mathrm{Mn}$ are shown in Figure 8. Both element concentrations outnumber the concentrations normally found in modern man $\left(42-160 \mu \mathrm{g} \mathrm{g}^{-1}\right.$ for Fe and $0.32-0.98 \mu \mathrm{g} \mathrm{g}^{-1}$ for $\mathrm{Mn}$, both at the $80 \%$ range [2]), with values which are ca. 100 and 10,000 times higher, for Fe and Mn respectively. There is no doubt that both $\mathrm{Fe}$ and $\mathrm{Mn}$, possibly under different geochemical conditions, are deposited onto the bones by the groundwater. Natural cavities in the bones and small postmortem cracks will allow these elements to be deposited to some degree also in compact bone tissue.

\section{Calcium, Sr, Ba, and $\mathrm{Mg}$}

The elemental ratios of $\mathrm{Sr}, \mathrm{Ba}$ and $\mathrm{Mg}$ to $\mathrm{Ca}$ are shown in Figure 9. It is characteristic that in AG104 all three elemental concentration ratios are more or less similar in both compact and trabecular tissues. Since there is no difference between compact and trabecular tissue in general, it is unlikely that any of these elements are brought to the bones by diagenetic processes. AG93 shows more variation and generally higher $\mathrm{Ba} / \mathrm{Ca}$ and
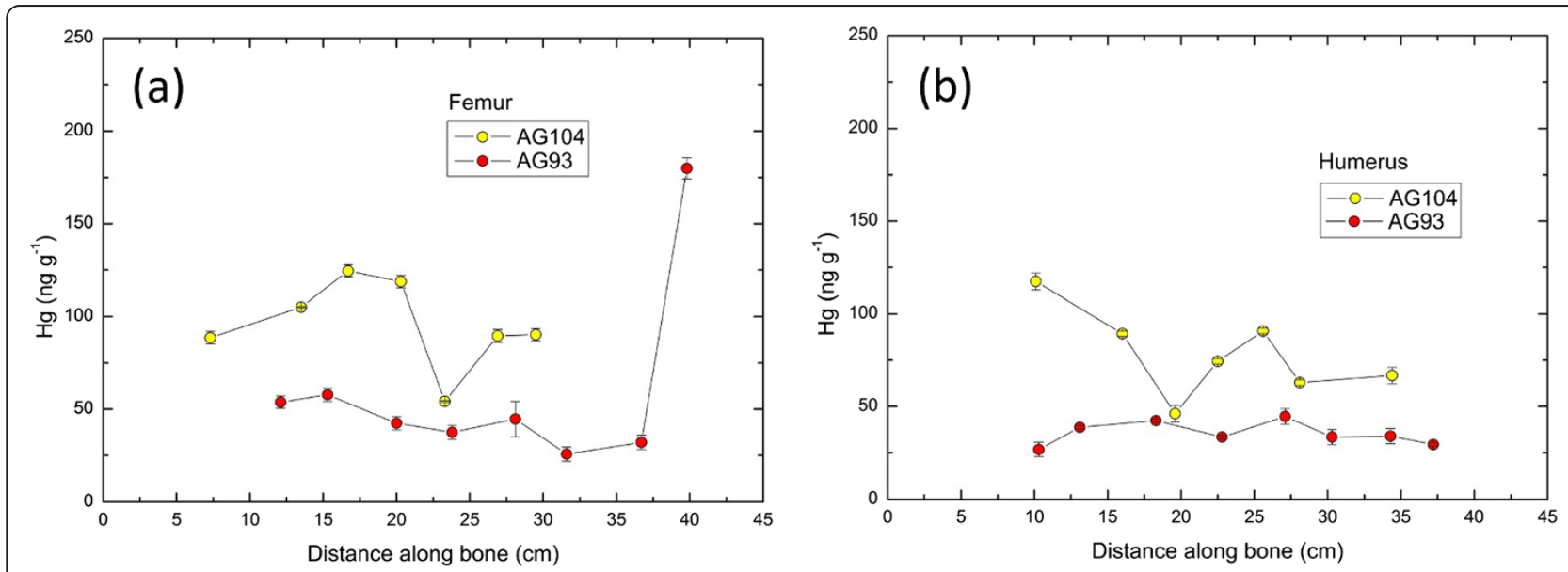

Figure 5 Mercury measured along femur and humerus. a: Hg measured on compact bone samples taken along the posterior of femur. X-axis in $\mathrm{cm}$, zero is at the top of caput femoris. $\mathbf{b}$ : Hg measured on compact bone samples taken along the backside of humerus. $X$-axis in $\mathrm{cm}$, zero is at the top of caput humeri. The last sample in the femur of AG93 also included small amounts of trabecular tissue. The error bars represent \pm 2 standard deviations of the total analytical uncertainty. 


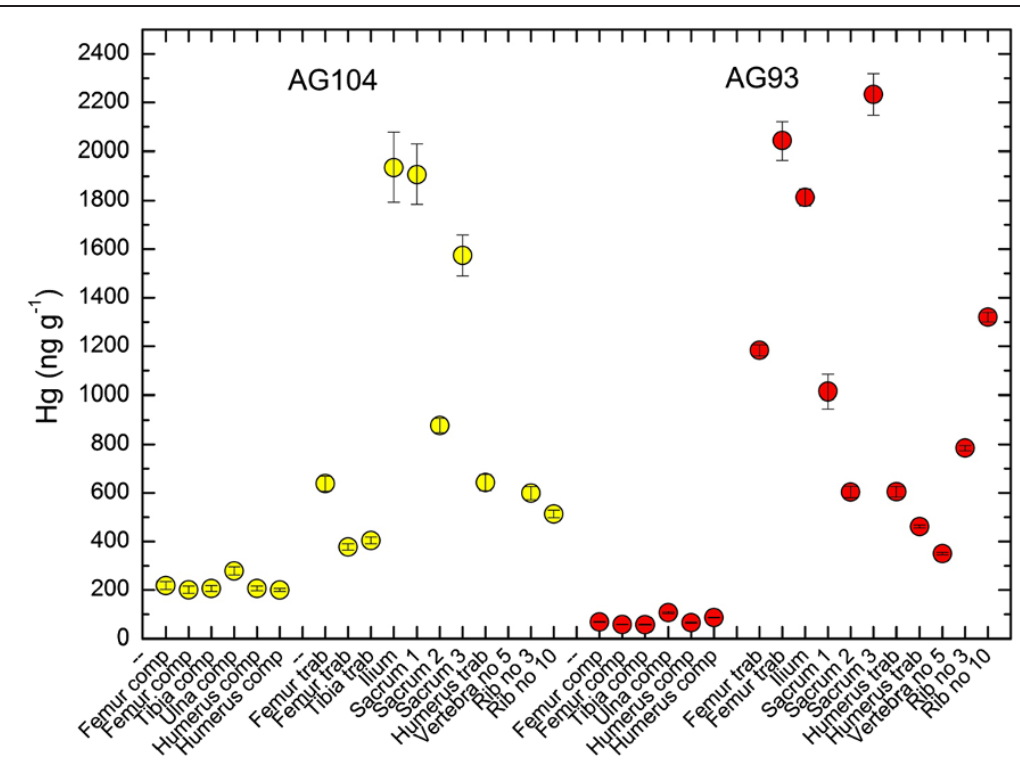

Figure 6 Mercury measured in compact and trabecular tissues. AG104 marked with yellow points, AG93 with red.

$\mathrm{Sr} / \mathrm{Ca}$ ratios in the trabecular tissues than in the compact. The variation in $\mathrm{Mg} / \mathrm{Ca}$ exhibits a much larger variation in both types of tissue in AG93. The turnover rate of trabecular tissue is generally higher than in compact bone tissue, and we propose that the variation seen could be due to differences in the concentrations of the bioavailable $\mathrm{Sr}, \mathrm{Ba}$ and $\mathrm{Mg}$ at two (or more) locations where AG93 have lived, i.e. reflecting the provenance at two or more times in his life.

\section{Discussion}

\section{Mercury}

Apart from a low level ubiquitous environmental occurrence $\mathrm{Hg}$ was not widespread in the medieval societies. In analogy with the present day the major environmental source in the medieval time was probably fish in which $\mathrm{Hg}$ is biomagnified and present as methylmercury [5-7]. Besides this small environmental exposure $\mathrm{Hg}$ was mainly present in the form of occasional, distinct point

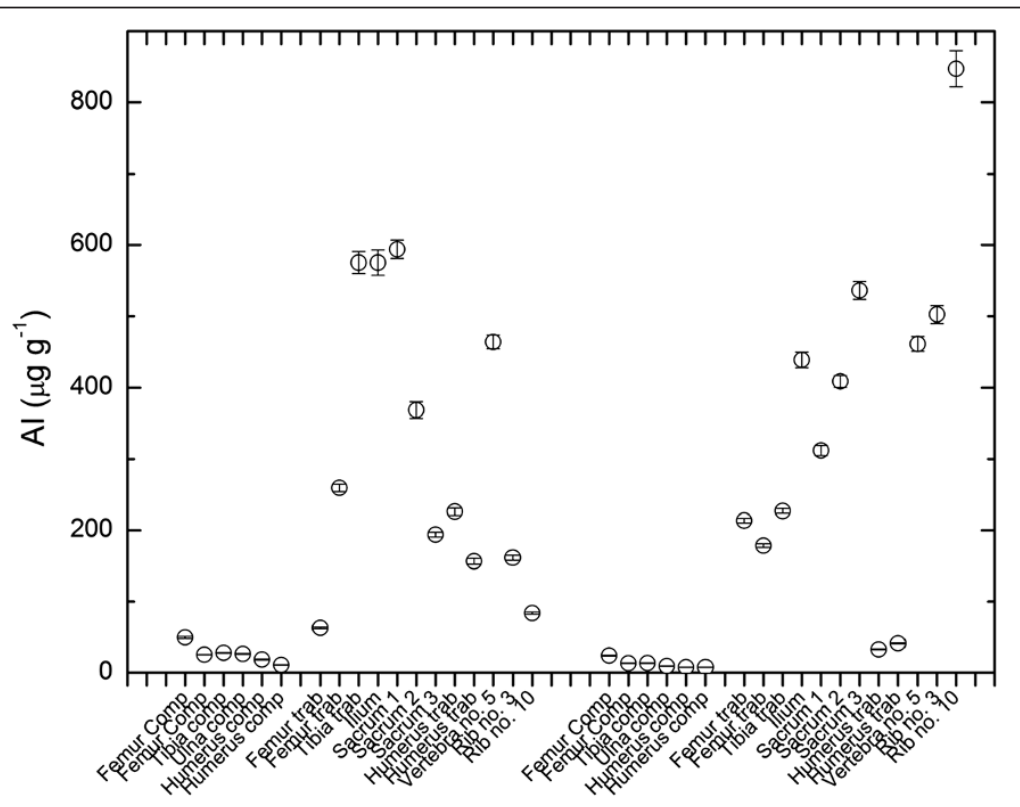

Figure 7 Aluminium in $\boldsymbol{\mu g ~ g}^{-1}$ determined by ICP-MS in the bone samples of AG93 and AG104. The error bars represent \pm 2 standard deviations of the analytical uncertainty. 


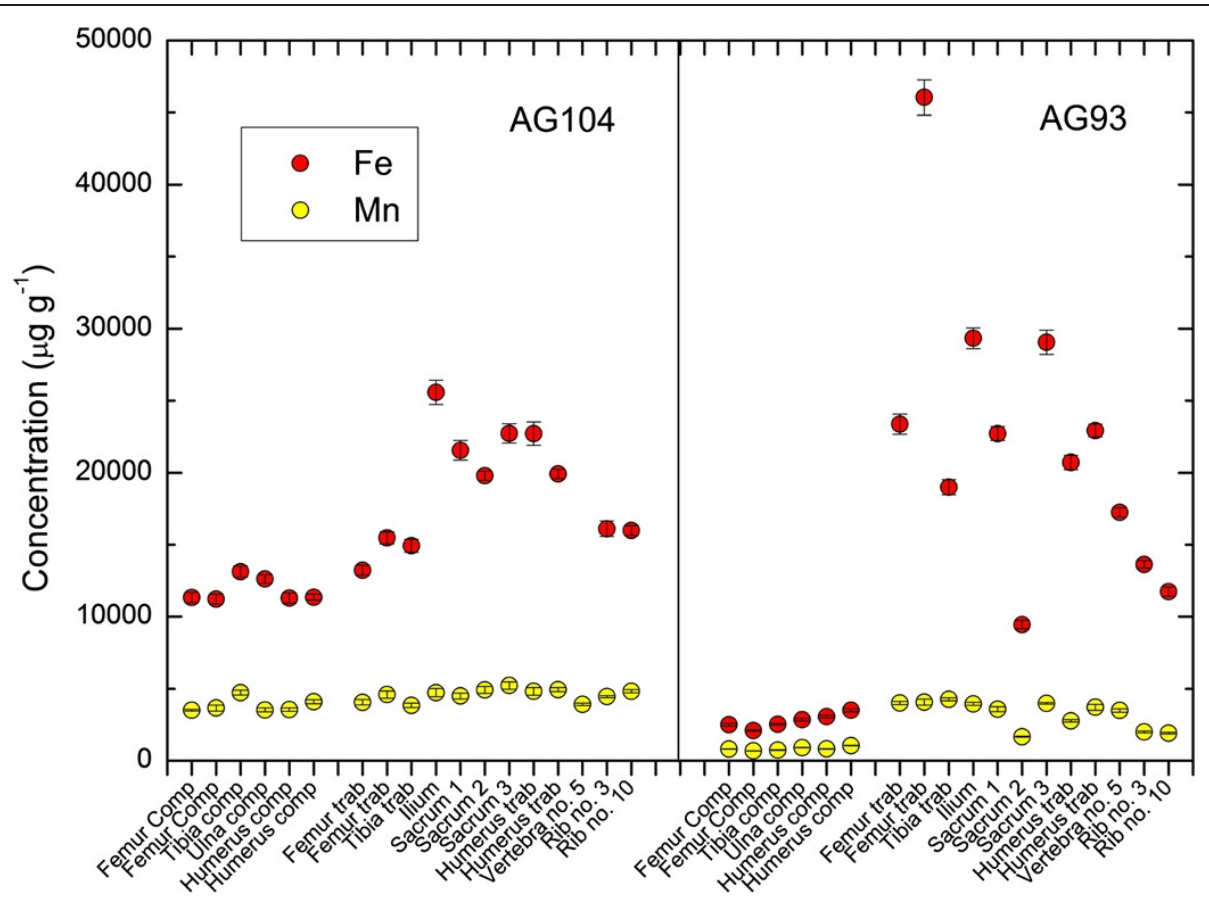

Figure 8 Measurements of Fe and Mn. Iron (red points) and Mn (yellow points) in $\mu \mathrm{g} \mathrm{g}^{-1}$ for compact and trabecular tissue in both AG104 (left) and AG93 (right). The error bars represent \pm 2 standard deviations of the analytical uncertainty.

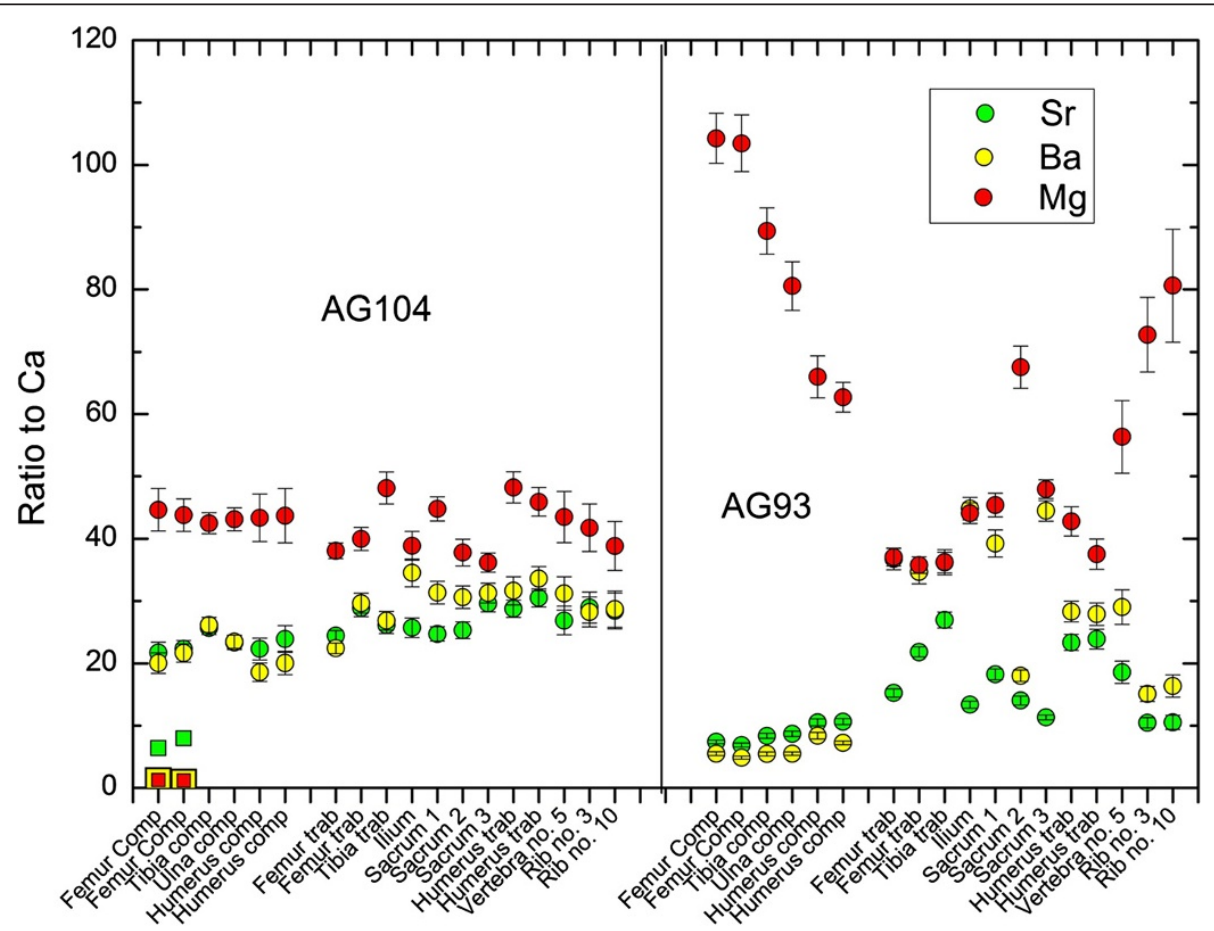

Figure 9 Measurements of Sr, Ba, Mg and Ca. Sr/Ca concentration ratios (green circles), Mg/Ca (red circles), and Ba/Ca (yellow circles) for AG104 (left) and AG93 (right). Squares representing the averages of 12 individuals from the Tirup cemetery (left) and 77 individuals from the Dominican Friary in Schleswig (right), in the same colour code as the circles. The average ratios from Tirup and the Dominican Friary in Schleswig are also listed in Table 1. The error bars represent \pm 2 standard deviations of the analytical uncertainty. 
sources, in contrast to for example $\mathrm{Pb}$ which was ubiquitous in the surroundings of all humans in medieval times, e.g. in the glazing of ceramics used for foodstuff, coins, roof tiles, window panes and even water pipes. The culturally defined potential point sources were: 1) the usage of $\mathrm{Hg}$ in medicine; 2) the use of cinnabar as a colour pigment in illuminating manuscripts and in paintings; 3) the application of gold onto other metals using amalgamation gilding; and finally 4) in the use of cosmetics (Vitruvius, book 7, chapter 8, section 4; Pliny the Elder book 29, chapter 8; [3-8]). In medieval Denmark the latter two must have been very rare, and we are left with main exposure ways either through medicine or through literary/academic work, both of which were mostly carried out in monastic environments [3].

Studies of modern day humans indicate that ingestion of $\mathrm{Hg}$ in individuals who are in $\mathrm{Hg}$-equilibrium results in a body burden of approximately 100 times the daily intake, while the half-life of $\mathrm{Hg}$ in the body is about 70 days [9]. Mercury is excreted through faeces and urine. Over periods longer than 49 days the faeces account for $33-35 \%$ of the $\mathrm{Hg}$ excretion and the urine ca. $3.3 \%$ according to [10]. In a group of modern day non-exposed Japanese workers the $\mathrm{Hg}$ concentrations in the urine averaged $119 \mu \mathrm{g} \mathrm{L}^{-1}$ [11]. In modern day humans the organic $\mathrm{Hg}$ (methylmercury) constitutes some $10-20 \%$ of the total $\mathrm{Hg}$ in most tissues, except in the kidney and in hair where it is 2 and 63\% respectively [5]. We have been unable to locate studies reporting the $\mathrm{Hg}$ speciation in the skeleton organ of modern man. Rasmussen et al. [3] concluded that the Hg concentration level in samples of compact femoral bone in nonexposed medieval and renaissance Danish individuals was between 10 and $100 \mathrm{ng} \mathrm{g}^{-1}$.

The large concentrations of $\mathrm{Hg}$ seen in the trabecular tissues are most likely not caused by contamination from the soil, as Rasmussen et al. [3] showed that there were no signs of diffusive processes in the $\mathrm{Hg}$ soil profiles they measured. Studying the details of the distribution of $\mathrm{Hg}$ in the two individuals investigated here two conclusions can be reached, namely that $\mathrm{Hg}$ is rather uniformly distributed in the compact bone tissue, and that $\mathrm{Hg}$ concentrations are generally higher in trabecular tissue and concentrated towards the abdomen region, as can be seen in two graphical displays in Figure 10. The central abdomen region is characterized by a large proportion of trabecular bone.

Two hypotheses can be presented as to what caused the higher $\mathrm{Hg}$ concentration values in trabecular tissue, extending up to 40 times the values of the compact bone tissue. The first hypothesis builds on the assumption that the $\mathrm{Hg}$ concentrations of the trabecular and the now decayed soft tissue were more or less similar and that the $\mathrm{Hg}$ content of the soft tissue was deposited onto the trabecular tissue upon decay of the body. During life

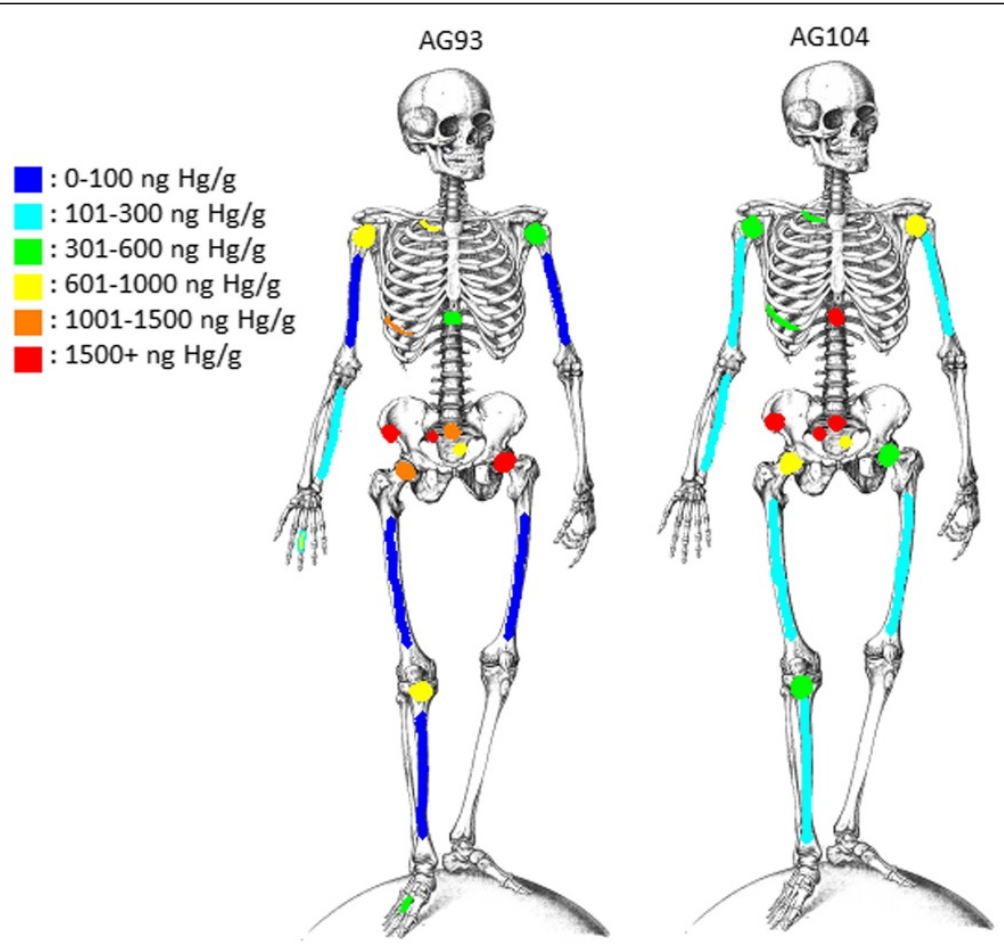

Figure 10 The $\mathrm{Hg}$ concentrations are depicted in colour codes for the two individuals. The colour code legend is shown to the left. Only the analysed bone elements are coloured. A concentration around the abdomen region is quite pronounced. 
the trabecular tissue was intermixed with soft tissue bone marrow, blood vessel, nervous tissue and fat - and if the $\mathrm{Hg}$ concentrations in the soft tissues were more or less similar to that of the compact bone tissue, then we underestimated the sample weight in our calculations. We have used the sample weight of the trabecular bone tissue preserved today, which is without the weight of the soft tissue now missing.

The second hypothesis is that the $\mathrm{Hg}$ is (or was) to a large degree present in organic form as methylmercury and therefore mainly present in the nervous tissue and the fat, rather than in the bone apatite. Should the $\mathrm{Hg}$ be present in bone apatite, it would likely be present in ionic form substituting for $\mathrm{Ca}^{2+}$. If the $\mathrm{Hg}$ was present in organic form it is likely that the $\mathrm{Hg}$ would concentrate in the soft tissues which are intermixed with the trabecular bone. After decay of the soft tissue the $\mathrm{Hg}$ will still be present inside the bone, only now collapsed onto the lamellae of the trabecular bone tissue making the overall concentration much higher than the compact bone value.

The first hypothesis can be brought to the test by estimating the original weight of trabecular tissue including the soft tissue by measurements of the bone compactness by CT-scanning. This has been done on a selection of the bones included in the present study. In the last column of Additional file 2: Table S1 is listed the measured compactness, $k$, and the $\mathrm{Hg}$ concentration corrected for this compactness. For AG104 such a correction brings the corrected $\mathrm{Hg}$ values quite close to the average $\mathrm{Hg}$ concentration in the compact tissue, $R C_{t}=$ 1.2 (test for $R C_{t}=1: \mathrm{t}=0.96, \mathrm{df}=5, \mathrm{p}=0.19$ ) where one sample is excluded as a very obvious outlier. The sample excluded is a sample of a vertebra that could easily be affected by proximity to inner organs which could accumulate Hg. However, even after applying the correction, the corrected $\mathrm{Hg}$-values are still very high for the nonexposed individual AG93, $R C_{t}=4.7$ (test for $R C_{t}=1: \mathrm{t}=$ 4.91, $\mathrm{df}=4, \mathrm{p}=0.002$ ), which is calculated excluding one anomalously high sample, again this sample originates from a bone surrounding the central cavity of the body, a rib. At face value the data of AG93 therefore contradicts hypothesis number one.

For elements not in equilibrium, $R C_{t}$ will differ from one. Tissue in the living human body undergo turnover as part of the process of remodelling and replacement. However, the turnover rate is not the same in all tissues. In general, turnover rates are much higher in soft tissues than in bones. Specific elements might accumulate in certain organs (like iodine in the thyroid gland). However, the way specific elements accumulate in different organs is not fully understood in all cases. There might therefore be a yet unknown reason why $\mathrm{Hg}$ may accumulate in the bones surrounding the abdomen. Bone turnover rates are also variable. The slowest turnover is generally found in the compact tissue of the long bones [2]. Compact bone tissue in an area of major muscle attachments (like the linea aspera on the back side of the femur) probably has a substantively higher turnover rate than the surrounding compact femoral bone. Skeletal turnover rates are highest in trabecular bone [12,13]. Furthermore, in individuals where exposure to a given element has taken place mainly long before death $R C_{t}$ will be lower than one, as more substance will be retained in compact bone than in trabecular bone and soft tissue. In individuals where the exposure was highest close to the time of death $R C_{t}$ will be higher than one, as the concentration of the element will be highest in soft tissue and trabecular bone.

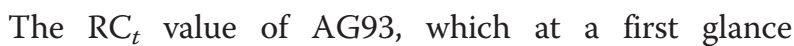
contradicted hypothesis number one, could therefore have another explanation. The high $\mathrm{RC}_{t}$ value for $\mathrm{AG93}$ could be explained if he was exposed to $\mathrm{Hg}$ only quiet late in life, i.e. shortly before his death. If such a scenario, where the distribution of $\mathrm{Hg}$ between compact and trabecular tissue is determined by the timing of the $\mathrm{Hg}$-exposure, is viable then the Hg-exposure of AG104 must have happened at least some years prior to his death, whereas the low exposure of AG93 took place very late in his life. A background exposure late in life could for instance be caused by AG93 starting to eat fish late in life. This scenario, which can be termed chemical life history, is an alternative explanation to the two 'static' hypotheses presented above.

Judging from analyses of modern man it is unlikely that hypothesis number two can be the sole explanation, as methylmercury only constitutes about $10-20 \%$ of the total mercury in most tissue types [5].

Sites of attachment of muscles onto the bones are particular prone to remodelling of compact bone tissue. Such a site is linea aspera on the femur, where one of the large leg muscles adheres to the femur. We have analysed a sample of linea aspera in each skeleton, i.e. samples termed KLR8601-c9 and KLR8602-c9. As comparative material a sample was procured 90 degrees on either side of the femur (samples KLR8601-c10, KLR8601-c11, KLR8602-c10, and KLR8602-c11). In the non-exposed AG93 the three values c9, c10 and c11 are very similar $\left(29,31\right.$ and $\left.20 \mathrm{ng} \mathrm{g}^{-1}\right)$. However, in the $\mathrm{Hg}$ exposed individual AG104 the sample of linea aspera, c9, is approximately two times higher than c10 and c11 (211, 119 and $124 \mathrm{ng} \mathrm{g}^{-1}$, respectively). This is an excellent observation showing how $\mathrm{Hg}$ is more easily incorporated into the compact tissue of linea aspera, if $\mathrm{Hg}$ is present in excess.

\section{Diagenesis}

The issue of diagenesis is very complex indeed, and many different aspect of diagenesis is described in detail 
by [14]. The particular case of possible diagenesis in connection with $\mathrm{Hg}$ was explored by [3], who measured horizontal and vertical soil profiles emerging from ca. $10 \mathrm{~cm}$ distally from caput femuris and 20 to $50 \mathrm{~cm}$ away from the body. These profiles were not consistent with diffusion profiles and it was concluded that no mobilisation of $\mathrm{Hg}$ took place on these scales, at least not in the three cases investigated from the cemetery in Tjærby, Denmark.

We have extended the search for diagenetic processes by including studies of soil invading cavities and cracks in the bone and of groundwater depositing elements onto the bone. The invasion of soil can be traced by monitoring elements typical for clay minerals, as e.g. done by Fernandes et al. [15], who measured trivalent $\mathrm{La}$, which substitutes for $\mathrm{Al}$ in clay minerals. In the present study we have analysed for $\mathrm{Al}$ itself, the concentrations of which is shown in Figure 7. As can be expected little or no soil invasion was observed in the compact bone tissue, as the $\mathrm{Al}$ concentrations the trabecular samples were up to a factor of 50 higher than in the compact tissue. It makes no sense to impose a correction for the compactness in the case of $\mathrm{Al}$, because there is no possibility of the majority of the $\mathrm{Al}$ to have originally been residing in the soft tissue. It is therefore inferred that elevated levels of $\mathrm{Al}$ must be due to soil invasion into the trabecular tissue. It should be noted that no decontamination were attempted during sampling of the trabecular tissue - it was simply not possible given the nature of the material, whereas the entire surface layer of the compact bones were removed prior to sampling. The samples of trabecular tissue were therefore analysed 'as found', which in some cases included invaded soil. In three cases, the trabecular part of the right femur of AG104, the trabecular part - right and left - of AG93, the $\mathrm{Al}$ concentrations determined were at the same low level of the compact bone samples (see Figure 7). We interpret this in the way that these three bone elements were intact and sealed, and that no soil had penetrated into the interior of these particular bones.

Besides soil invasion, diagenesis could also have taken place by seeping groundwater depositing previously dissolved ionic compounds. At some hydrological locations the groundwater carries large amounts of $\mathrm{Fe}$ and $\mathrm{Mn}$ [16-18], and the lay cemetery of Svendborg Franciscan Friary is such a place. The landscape rises steeply to the west of the friary, and the hillside running north-south here carries and releases a lot of groundwater. This was in all likelihood also the case in medieval times, as there was a water fountain ca. $10 \mathrm{~m}$ due west of the west wing which is discernible even today, and a relatively large water supply or sewer system in the brickworks of the Northern part of the west wing was observed during the 2007 excavation (Thomsen in prep).
The precise effect of the thorough mechanical decontamination of the compact bone tissue in the sampling phase was investigated by analysing the normally disposed outer surface tissue. This was done for one sample in each skeleton, KLR8601-c11u and KLR8602-c11u. Not unexpectedly the Al concentration is larger by a factor of ca. 10 and 20, respectively, as the outer surface of the bones have been in direct contact with the soil. What is more interesting is that the $\mathrm{Hg}$ in the surface layer is higher by factors of 16 and 19, respectively. This is surely not contamination from the environment, but most likely $\mathrm{Hg}$ from decomposed soft tissue deposited on the surface of the bone.

It must be expected that the trabecular tissue is more susceptible to groundwater deposition, as it has a vastly larger surface area exposed to the groundwater over the centuries, provided that the groundwater can indeed penetrate to the interior of the long bones. It is seen from Figure 7 that AG104 exhibits a uniform distribution of Mn with similar concentration values in the compact and the trabecular tissues. The average Mn-concentration of both types of tissues in AG104 is $4340 \mu \mathrm{g} \mathrm{g}^{-1}$. In AG93 there is, however, a pronounced difference between the compact tissues and the trabecular tissue samples, the trabecular types being higher in $\mathrm{Mn}$. The compact bone samples in AG93 showed an average Mn concentration of $820 \mu \mathrm{g} \mathrm{g}^{-1}$ and the trabecular $3360 \mu \mathrm{g} \mathrm{g}^{-1}$. Taking the combined data into consideration it is possible that the bones of AG104 and AG93 have been subjected to the same flow of groundwater leading to a uniform deposition of $\mathrm{Mn}$ of approximately $4000 \mu \mathrm{g} \mathrm{g}^{-1}$; only in AG93, it seems, has the groundwater penetrated into the compact bone tissues. It should be noted that the Mn-deposition seen in this study is anomalously high compared to other archaeological sites in the region. In the Dominican Friary in Schleswig in Northern Germany Mn-concentrations of ca. $30 \mu \mathrm{g} \mathrm{g}^{-1}$ are normal and in individuals from the Tirup cemetery outside Horsens in Denmark concentrations of ca. $150 \mu \mathrm{g} \mathrm{g}^{-1}$ are normally seen (unpublished results). These differences are undoubtedly caused by differences in the hydrological regimes of the cemeteries.

Iron is a factor of 2 elevated in the trabecular samples in AG104 relative to the compact samples (average Fe: compact $11,820 \mu \mathrm{g} \mathrm{g}^{-1}$ and trabecular 23,630 $\mu \mathrm{g} \mathrm{g}^{-1}$ ). For AG93 the trabecular tissue is on average 8 times higher in Fe concentrations - indicating that groundwater deposition of $\mathrm{Fe}$ over the years has been much more severe for this skeleton.

However, neither soil invasion nor groundwater deposition of $\mathrm{Fe}$ and $\mathrm{Mn}$ can be seen to have influenced the other elements analysed in samples of decontaminated compact bone samples, and it seems unlikely that the action of the groundwater have changed the concentrations of $\mathrm{Hg}, \mathrm{Ba}, \mathrm{Sr}$ or $\mathrm{Mg}$ in the skeletons. 


\section{Provenance}

Much attention has been given recently to Sr-isotopes as an indicator of provenance (e.g. [19]). However, the ratios $\mathrm{Mg}, \mathrm{Sr}$ and $\mathrm{Ba}$ to $\mathrm{Ca}$ have also been utilized to monitor differences in provenance (e.g. [20-22]). The $\mathrm{Mg} / \mathrm{Ca}$ ratio shows some relatively large variations, whereas the $\mathrm{Sr} / \mathrm{Ca}$ and the $\mathrm{Ba} / \mathrm{Ca}$ ratios show less variation. The compact bone samples yield less variation than the trabecular samples. The trabecular tissue has the highest turnover rate and is therefore indicative of the provenance late in the life of the individuals. The best estimate of the provenance of Svendborg medieval town is therefore approximated by the following average ratios calculated from the trabecular bone tissues: $\mathrm{Sr} / \mathrm{Ca}=27.3 \pm 2.1, \mathrm{Ba} /$ $\mathrm{Ca}=30.0 \pm 3.2$ and $\mathrm{Mg} / \mathrm{Ca}=41.8 \pm 4.2$ (for $\mathrm{AG} 104$ ); and $\mathrm{Sr} / \mathrm{Ca}=18.2 \pm 6.2, \quad \mathrm{Ba} / \mathrm{Ca}=31.5 \pm 10.1$ and $\mathrm{Mg} / \mathrm{Ca}=$ $49.3 \pm 15.3$ (for AG93).

The compact bone averages are: $\mathrm{Sr} / \mathrm{Ca}=22.8 \pm 2.5, \mathrm{Ba} /$ $\mathrm{Ca}=21.1 \pm 2.7$ and $\mathrm{Mg} / \mathrm{Ca}=42.6 \pm 2.9$ (for $\mathrm{AG} 104$ ); and $\mathrm{Sr} / \mathrm{Ca}=7.7 \pm 1.4, \mathrm{Ba} / \mathrm{Ca}=5.4 \pm 1.6$ and $\mathrm{Mg} / \mathrm{Ca}=91.5 \pm$ 14.5 (for AG93). In the lower left corner of Figure 9 squares indicate the averages of the $\mathrm{Ba} / \mathrm{Ca}, \mathrm{Sr} / \mathrm{Ca}$ and $\mathrm{Mg} / \mathrm{Ca}$ ratios measured on samples of various compact and trabecular bones from 77 individuals interred at the Dominican Friary in Schleswig, Germany, and 12 such samples from Tirup cemetery outside Horsens, Denmark (unpublished data). It is seen that the compact bone values from AG93 are similar to Tirup and Schleswig in $\mathrm{Sr} / \mathrm{Ca}$ and $\mathrm{Ba} / \mathrm{Ca}$ ratios, but very different in $\mathrm{Mg} / \mathrm{Ca}$ ratios. AG104 is altogether different from Tirup and Schleswig in all three ratios.

It seems likely that AG93 was a migrant, who had lived for a prolonged time at some other place than Svendborg where he was eventually buried. AG104, on the other hand, seems to have been stationary in Svendborg throughout his relatively short life.

\section{Other elements}

The rest of the elements, $\mathrm{Zn}$, As and $\mathrm{Pb}$, show little variation in the samples analysed as can be seen by the factor loadings shown in Figure 2. It is possible and even likely that $\mathrm{Zn}, \mathrm{As}$ and $\mathrm{Pb}$ have all been substituting for $\mathrm{Ca}$ in the bone apatite. The fact the $\mathrm{Zn}$ seems not to exhibit any large systematic variation is consistent with $\mathrm{Zn}$ being strongly controlled by metabolic processes in the body. There are no indications that $\mathrm{As}$ and $\mathrm{Pb}$ are strongly metabolically controlled elements, and the explanation for their lack of variation may simply be that these elements have been more or less homogenous in the food and environment of AG93 and AG104.

\section{Conclusions}

We have measured $\mathrm{Mg}, \mathrm{Al}, \mathrm{Ca}, \mathrm{Mn}, \mathrm{Fe}, \mathrm{Zn}, \mathrm{As}, \mathrm{Sr}, \mathrm{Ba}, \mathrm{Hg}$ and $\mathrm{Pb}$ in 73 bone samples from two medieval individuals interred in the laymen cemetery of the Franciscan Friary of Svendborg. The trace element concentrations of the two individuals can be clearly distinguished by Principle Component Analysis, which also show a clear distinction between compact and trabecular bones tissues.

Mercury is almost uniformly distributed in all compact bone elements sampled in one individual. In the trabecular tissue $\mathrm{Hg}$ occurs in much higher concentrations than in compact bone. This can be due to either of two 'static' hypothesis: 1) that there were more less similar $\mathrm{Hg}$ concentrations in bone and soft tissues and that the original sample weight was underestimated in the trabecular bone tissue due to the loss of soft tissue; 2) that $\mathrm{Hg}$ was present in organic form and therefore mainly concentrated in the nervous tissue and fat in the bone marrow and that the $\mathrm{Hg}$ content of this decomposed tissue is now deposited onto the surface of the bone lamellae of the trabecular tissue. We argue that our data are in support of the first hypothesis, combined with high $\mathrm{Hg}$ exposure several years before death for AG104 and a low exposure towards the end of life for AG93. Our data therefore reflect what can be termed a chemical life history of the individuals.

If excess levels of $\mathrm{Hg}$ were present in the body it is more likely to be incorporated in compact bone tissue at sites of vivid remodelling, as has been demonstrated for linea aspera on the femur of AG104.

There are good indications from the present data and the literature that $\mathrm{Sr} / \mathrm{Ca}, \mathrm{Ba} / \mathrm{Ca}$ and $\mathrm{Mg} / \mathrm{Ca}$ can be used to reveal the provenance of the individual through life. Large differences can be seen in these elemental ratios for medieval individuals from Svendborg, Tirup and Schleswig. The elemental ratios differ between the two individuals investigated here, AG104 exhibits more or less constant ratios for all bones and he has therefore in all likelihood lived his entire life in Svendborg, while AG93 seems to have lived part of his earlier life somewhere else.

Diagenetic processes are reflected in the concentrations of $\mathrm{Al}, \mathrm{Fe}$ and $\mathrm{Mn}$. Soil invasion can be monitored by measuring $\mathrm{Al}$, typically present in clay minerals. Groundwater seems to have deposited Fe and Mn onto and to some degree into the bones of the individuals interred at the Franciscan Friary of Svendborg.

\section{Additional files}

\footnotetext{
Additional file 1: Franciscan Friary Svendborg Denmark.

Additional file 2: Table S1. Results of the elemental analyses by CV-AAS $(\mathrm{Hg})$ and ICP-MS (all other elements). First column: Laboratory numbers. Second column: tissue type. Third column: sample weight in grams. Secondnext-to-last column: Compactness measured by CT-scanning ( $\mathrm{k}$ in formulae 2). Next-to-last column: corrected $\mathrm{Hg}$ concentration $\left(\boldsymbol{C}_{\mathrm{t}} \cdot \mathrm{k}\right.$ from formula 3 ). Last column $\mathrm{RC}_{\mathrm{t}} \cdot \mathrm{k}$ (from formula 3 ) - the ration between the corrected $\mathrm{Hg}$ concentration $\left(C_{t} \cdot k\right)$ and the average compact bone $\mathrm{Hg}$ concentration $\left(C_{c}\right)$.
} 


\section{Competing interests}

The authors declare that they have no competing interests.

\section{Authors' contributions}

$L S, C P$ and $A L$ performed various parts of the chemistry. KLR drafted the manuscript. PML performed the CT-scanning. JLB performed the anthropological examinations. All authors read and approved the final manuscript.

\section{Acknowledgements}

This work was supported by EU Interreg 4a through the project Bones4Culture. Pia Klingenberg Haussmann is thanked for technical assistance in this project. Two anonymous referees are thanked for constructive criticisms.

\section{Author details}

${ }^{1}$ Institute of Physics, Chemistry and Pharmacy, University of Southern Denmark, Campusvej 55, Odense M DK-5230, Denmark. ${ }^{2}$ Institute of Forensic Medicine - ADBOU, University of Southern Denmark, Lucernemarken 20, Odense S DK-5260, Denmark. ${ }^{3}$ Arkæologi Sydfyn, Grubbemøllevej 13, Svendborg 5700, Denmark.

Received: 28 February 2013 Accepted: 22 March 2013

Published: 6 April 2013

\section{References}

1. Grupe G: Impact of the choice of bone samples on trace element data in excavated human skeletons. J Archaeol Sci 1988, 15:123-129.

2. ICRP Publication 23: Reference Man: Anatomical, Physiological and Metabolic Characteristics. 1st edition. Elsevier; 1975.

3. Rasmussen KL, Boldsen JL, Kristensen HK, Skytte L, Hansen KL, Mølholm L, Grootes PM, Nadeau M-J, Eriksen KMF: Mercury levels in Danish medieval human bones. J Archaeol Sci 2008, 35(8):2295-2306.

4. Kristensen HK: The Franciscan Friary of Svendborg. The archaeology of Svendborg. Denmark: Svendborg County Museum; 1994:110. Volume 6.

5. Sumino K, Hayakawa K, Shibata T, Kitamura S: Heavy metals in normal Japanese tissues. Arch Env Health 1975, 30:487-494.

6. lyengar $\mathrm{V}$, Woittiez $\mathrm{J}$ : Trace elements in human clinical specimens: evaluation of literature data to identify reference values. Clin Chem 1988, 34:474-481.

7. Zhang $Y$, Nakai S, Masunaga S: An exposure assessment of methyl mercury via fish consumption for the Japanese population. Risk Anal 2009, 29(9):1281-1291.

8. Rasmussen KL, Torino M, Glastrup J, Ramseyer NT, Bjerregaard P: On the embalmment of S. Francesco Caracciolo Archaeometry 2012, 54(6):1100-1113.

9. Baselt RC: Disposition of toxic drugs and chemicals in Man. Seal Beach, California: Biomedical Publications; 2011.

10. Aberg B, Ekman L, Falk R, et al: Metabolism of methyl mercury $\left({ }^{203} \mathrm{Hg}\right)$ compounds in man. Arc Env Health 1969, 19:478-484.

11. Nakayama $E$, Momotani H, Ishizu S: A pattern of urinary mercury excretion in workers exposed to mercury vapor of relatively low and constant concentration. In Clinical chemistry and clinical toxicology of metals. Edited by Brown SS. New York: Elsevier/North Holland; 1977:209-212.

12. Lee CA, Einhorn TA: The Bone Organ System: Form and Function. In Osteoporosis. 2nd edition. Edited by Marcus R, Feldman D, Kelsey T. San Diego, CA: Academic; 2001:3-20.

13. Ruimerman R: Modeling and remodeling in bone tissue. Thesis: Technische Universiteit Eindhoven; 2005.

14. Hedges REM: Bone diagenesis: an overview of processes. Arcaheometry 2002, 44(3):319-328.

15. Fernandes R, Hüls M, Nadeau M-J, Grootes PM, Garbe-Schönberg C-D, Hollund HI, Lotnyk A, Kienle L: Assessing screening criteria for the radiocarbon dating of bone mineral. Nuclear Instruments and Methods in Physics Research B 2012. In press.

16. Keeley HCM, Hudson GE, Evans J: Trace element contents of human bones in various states of preservation. J Archaeo/ Sci 1977, 4:19-24.

17. Lopez-Gonzalez F, Grandal-d'Anglade A, Vidal-Romani JR: Deciphering bone depositional sequences in caves through the study of manganese coatings. J Archaeol Sci 2006, 33:707-717.

18. Kuczomow A, Cukrowska E, Stachnuik A, Gaweda R, Mroczka R, Paszkowicz W, Skrzypiec K, Falkenberg R, Backwell L: Incvestigation of chemical changes in bone material from South Africa fossil hominid deposits. J Archaeol Sci 2010, 37:107-115.

19. Frei KM, Frei R: The geographic distribution of strontium isotopes in Danish surface waters - A base for provenance studies in archaeology, hydrology and agriculture. Appl Geochem 2012, 26:326-340.

20. Schutkowski H, Herrmann B, Wiedemann F, Bocherens H, Grupe G: Diet, status and decomposition at Weingarten: trace element and isotope analyses on early mediaeval skeletal material. J Archaeol Sci 1999, 26:675-685.

21. Fabig A: Spurenelementuntersuchungen an bodengelagertem skelettmaterial validitätserwägungen im kontext diagnetisch bedingter

konzentrationsänderungen des knochenminerals. Georg-August-Universität, Göttingen: Dr. Thesis; 2002. 912 pp.

22. Cucina A, Tiesler V, Sosa TS, Neff H: Trace-element evidence for foreigners at a Maya port in Northern Yucatan. J Achaeol Sci 2011, 38:1878-1885.

doi:10.1186/2050-7445-1-10

Cite this article as: Rasmussen et al:: The distribution of mercury and other trace elements in the bones of two human individuals from medieval Denmark - the chemical life history hypothesis. Heritage Science 2013 1:10.

Publish with ChemistryCentral and every
scientist can read your work free of charge
"Open access provides opportunities to our
colleagues in other parts of the globe, by allowing
anyone to view the content free of charge."
W. Jeffery Hurst, The Hershey Company.
- available free of charge to the entire scientific community
- peer reviewed and published immediately upon acceptance
- cited in PubMed and archived on PubMed Central
- yours - you keep the copyright
submit your manuscript here:
http://www.chemistrycentral.com/manuscript/

